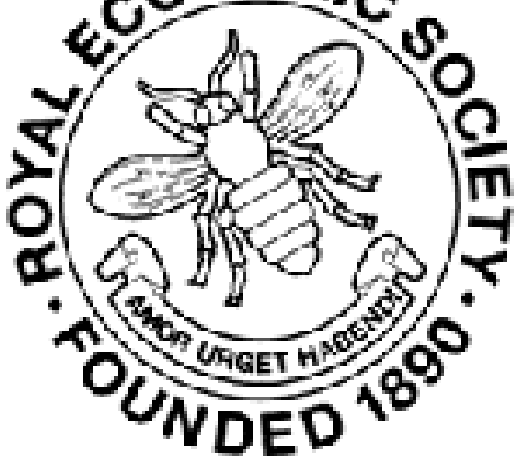

Depreciation and Sinking Funds in Municipal Undertakings

Author(s): S. H. Turner

Source: The Economic Journal, Vol. 14, No. 53 (Mar., 1904), pp. 47-56

Published by: Wiley on behalf of the Royal Economic Society

Stable URL: http://www.jstor.org/stable/2220738

Accessed: 25-06-2016 05:52 UTC

Your use of the JSTOR archive indicates your acceptance of the Terms \& Conditions of Use, available at

http://about.jstor.org/terms

JSTOR is a not-for-profit service that helps scholars, researchers, and students discover, use, and build upon a wide range of content in a trusted digital archive. We use information technology and tools to increase productivity and facilitate new forms of scholarship. For more information about JSTOR, please contact support@jstor.org.

Royal Economic Society, Wiley are collaborating with JSTOR to digitize, preserve and extend access to The Economic Journal 


\section{DEPRECIATION AND SINKING FUNDS IN MUNICIPAL UNDERTAKINGS ${ }^{1}$}

WITH the rapid growth of the industrial domain of municipalities and the large increase of debt which is in a great measure due to that wider sphere of activity, certain questions of municipal finance have assumed an importance which warrants closer study than has hitherto been given to them. With the arguments for or against municipal trading this paper is not in the least concerned; it is limited to a few financial issues which appear to be of vital importance in the administration of such undertakings.

The particular questions to be raised connect themselves with the fact that all these undertakings are started with borrowed capital, and it is therefore important to understand what are the principles on which an equitable distribution of this initial burden may be made as between the present and the future generations of citizens. The Select Committee on Repayment of Loans by Local Authorities, which reported last year, has brought out the principles by which Parliament and the Departments have hitherto been guided in fixing the periods of repayment, and the evidence also includes the criticisms of those periods by representatives of various local bodies who are almost unanimous in asking for longer terms.

It is, I think, unfortunate that the Report of the Committee does nothing more than suggest slight alterations and adjustments here and there, without ever raising the question whether a practice which at its inception contemplated none of the recent extensions of municipal activity does not require radical alteration, and not merely slight adjustment, before it can be effective in the newer sphere. The terms of reference were wide enough to admit of such an inquiry being made, and there is strong

1 Read before the Economic Science Section of the British Association at Southport, 1903. 
reason to doubt whether an adequate solution can be found to many of the difficulties under which corporations now labour without first attempting to separate the conceptions of Sinking and Depreciation Funds. In many cases the one is of necessity contained in the other ; in many cases they should be kept quite distinct. It is the purpose of this paper to show that there is an unsatisfactory diversity of methods among municipalities which can only be obviated by a change of statutory requirements.

The present practice of Parliament and the Departments is to fix a period for the repayment of debts contracted by local authorities, so that for each loan there is a statutory Sinking Fund. Many factors are considered in fixing these periods for different undertakings. It is recognised to be unwise and unjust, even if it were practicable, to burden the ratepayers of one year or one decade with the whole cost of a necessary or useful undertaking which will benefit the future ratepayers quite as much as, if not more than, it will benefit the present. Many large municipalities, with a desire to preserve open spaces and parks in growing districts within their areas, have been actuated more by the needs of the next generation than of the present, and it would be the height of folly to penalise such foresight by making the present generation bear the whole cost. That the first generation should repay the loan for a large water undertaking would be equally absurd and unjust. On the other hand, it is almost as important a principle in present practice that the period should be kept as short as is consistent with efficient work, in order that the ratepayers of the future, who are assumed to have equally great tasks before them, may not be hampered by repayment of debts for works instituted by their predecessors. Hence, in the cases of land for parks and of waterworks, while there is no question of their becoming valueless, and perhaps little fear of their value diminishing for centuries, an accepted principle is that loans should scarcely ever exceed two generations. In view of the great increase of local indebtedness, again, it is urged that a short-period loan ensures more careful consideration by a municipality before entering upon a project, and that this is very desirable as a salutary check; while local circumstances, such as the possibility of a diminution of population, are also sometimes taken into account as pointing to the advisability of restricting the term. But the principal consideration given by the Government officials is that no debt should outlast the useful life of the works for which it is con- 
tracted, possibilities of obsolescence as well as wear and tear entering into this calculation. Therefore, in the case of a subject like tramways, where the useful life is comparatively short, that life is the chief, almost the sole determinant of the Sinking Fund period which the Government lays down; while in the case of a subject like a park or waterworks, where the useful life may be indefinitely long, the principle of not exceeding two generations is the real determinant.

Probably no very serious objection will be raised against these rules and principles so long as they are limited in their application only to certain classes of undertakings, though it is often urged that two generations is too short a period for the repayment of some debts, as e.g., where a permanent asset can be relied upon. They are in the main good and convenient, I think, for two classes of works :-

(a) Those unproductive undertakings which at one time were the chief purposes for which municipalities borrowed, and which still account for a large proportion of local debt.

(b) Those reproductive undertakings like great waterworks, which are almost permanent in character if repaired year by year out of revenue, and in which the Sinking Fund period is but a small part of the useful life.

But when these principles are applied, with perhaps merely a little additional emphasis on the life of the subject, to the large sphere of undertakings which have come recently under municipal control, it may well be questioned whether they are adequate to the needs. The actual result is that the debt on gasworks, tramways, \&c., has to be paid off in a period corresponding very nearly with the life of the subject, and when a sum has been set aside for this Sinking Fund every year there is in general no further obligation upon the municipality with regard to reserves. The life of the subject is short; yet, speaking generally, no Depreciation Fund is enforced, and we obtain from this a very wide divergence of practice from municipality to municipality. All of them must have Sinking Funds : some of them have adequate Depreciation Funds, some of them have either inadequate Depreciation Funds or none at all. Over the whole of municipal reproductive undertakings the Depreciation Funds are so small that they almost forfeit the name, as was clearly shown by Sir Henry Fowler's Return of the Reproductive Undertakings carried on by municipal boroughs in England and Wales issued in 1899, which is brought down to 1902 by a return issued last winter. According to the former return the annual average

No. 53.- - VOL. XIV. 
amount set aside for depreciation was under one-tenth of one per cent. on the capital borrowed, and it had increased to one-sixth of one per cent. in the later period.

In view of the constant use of these figures, especially by opponents of municipal trading, it is necessary to point out that they do not convey a fair idea. On the whole they may be assumed to be accurate, though they would be slightly more favourable to municipalities if the methods of book-keeping were uniform, for it is easy to see from the statements made in the returns about the disposal of profits that some small portion is set aside for depreciation though under some other name. But a much more important fact, which is left out of account in drawing conclusions from the figures, is that not every one of these reproductive undertakings is a proper subject for a Depreciation Fund. For instance, some of our large waterworks are fully maintained out of revenue, renewal of any part of the plant and even the institution of improved methods being met out of revenue year by year. Indeed it is urged that they may be quite as valuable assets sixty or eighty years hence after the whole debt is repaid as they are to-day, and where there is such maintenance of value a Depreciation Fund is not required. Even in cities where liberal Depreciation Funds are kept for other industries, expert opinion considers it quite unnecessary to require such a fund for the waterworks, when they are kept up to their fullest efficiency out of revenue each year. Now waterworks account for nearly half of the capital borrowed by municipalities for reproductive undertakings, and while it is not claimed that every waterworks has an indefinitely long life, I have given reasons for excluding this large sum from our estimate when we are calculating the amount of provision for depreciation. Other items, particularly where land plays a very important part, may be brought more or less under the same category, and so the bald statement that the municipalities are only putting aside one-sixth of one per cent. for depreciation in reproductive undertakings in England and Wales is calculated to mislead.

To obtain a true view we must confine ourselves to subjects which admittedly depreciate within a measurable period of time, and fortunately the material is available for making this study. There is some difference of opinion as to the life of a tramway undertaking, but it is usually said that the equated period should not be allowed to exceed thirty years. The Select Committee on Repayment of Loans could not see its way to recommend any 
extension of this period, especially when the possibility of obsolescence is taken into account, and even for the permanent way this period has often been found to be too long.

The facts for the municipal tramway undertakings of England and Wales according to the latest figures of the Return to the House of Commons in December last are these :

In 1902 the total capital borrowed amounted to $£ 9,443,741$, and the annual average Depreciation Fund was £50,307, or over one half of one per cent. I might remark in passing that this percentage would be higher if Scotland were included, because in that country, generally speaking, adequate Depreciation Funds are maintained: but I must point out, on the other hand, that tramways show the largest percentage set aside for depreciation of any municipal undertaking, that for gasworks in the same period being just over one-third of one per cent., and that for electrical supply being about one-sixth of one per cent. Even controversy as to what the lives of these subjects should be does not affect the result that the Depreciation Funds are absurdly inadequate.

The importance of this fact cannot be exaggerated. In no sphere of municipal finance is it easier than here to relieve the ratepayers of to-day at the expense of the future, while it may very occasionally happen that too large a part of the burden falls upon the present. Everything depends upon whether certain charges are made to capital account or to revenue account. It is not to be suggested that errors of this kind would be made intentionally, but they have already occurred through lack of knowledge, or even through trusting too implicitly to a statutory Sinking Fund. As an example of the gravity of the question I could give the case of a municipality which is now paying, and will for some years be paying, a Sinking Fund on tram lines which were taken up as worn out two years ago. Neither was there a Depreciation Fund in this case, and so the present is repaying capital borrowed for two sets of rails. In such a case, it is obviously the duty of a city to make more liberal provision than the law enjoins.

But to sum up concisely the results of present practice in these reproductive undertakings, even on the assumption that the Statutory Sinking Fund period in no case exceeds the useful life of the works, we have:

(1) Those municipalities in which the statutory requirement is the maximum provided. Here, on the assumption that thirty years is the equated life of the subject and is also the Sinking

E 2 
Fund period, at the end of the thirty years the loan is repaid, but the subject is worn out or obsolete and there is no fund for renewing it. The municipality must obtain powers to borrow afresh for the same undertaking and a system of borrowing, paying off in thirty years, borrowing again and paying off again, goes on for ever, without taking any account of new capital required for extension of the plant.

(2) Those municipalities in which more than the statutory requirement is provided.

(a) Where a slight Depreciation Fund is kept in addition to the Sinking Fund the borrowing and re-borrowing must go on in much the same way as in the former case, though the sum borrowed may grow less for one and the same undertaking at each re-borrowing.

(b) Where an adequate Depreciation Fund is kept in addition to the Sinking Fund, at the end of the period the whole debt will be paid off by the Sinking Fund and the plant will be up to its original value, or the money in the Depreciation Fund, together with the then value of the plant, will be equal to the original sum borrowed. In this case there will be no re-borrowing for the same undertaking, if we exclude extensions as new undertakings, and no further Sinking Fund will be required.

There are many variations within these classes, but judging from the figures I have given, the great bulk of municipalities either keep no Depreciation Funds at all or keep very inadequate ones: and this unsatisfactory divergence of practice becomes still worse when we hear demands from towns whose systems thus differ for lengthening the Sinking Fund periods. It is obviously very dangerous to grant such requests to those who only fulfil the minimum statutory requirements; a great deal may be said in favour of those which keep an adequate Depreciation Fund in addition.

The municipalities which adopt the minimum and those which do only a little more by way of an inadequate Depreciation Fund are not, however, without some show of reason for their practice. It is urged by them that since the life of the subject is the main factor in fixing the Sinking Fund period therefore the Sinking Fund is the Depreciation Fund. If you set aside a Depreciation Fund in addition to the Sinking Fund the life of the subject is taken into account twice over, and the undertaking is thus handicapped as no private company would be. The first thirty years on this system would not only repay the capital borrowed but would also build up an equal capital for succeeding 
generations who will have but one of these funds, viz.:-the Depreciation Fund, to pay. This, they say, would be manifestly unfair to the first generation. Besides, while we have for convenience considered the Sinking Fund period as corresponding with the life of the subject, it is usually put on the safe side; and so even where no specific Depreciation Fund is charged there is in a great many cases a surplus of value when the loan is repaid. The first generation repays the borrowed capital and often leaves a slight surplus of value to the next generation. Can anything more be expected of it?

The argument of those municipalities which do put aside a full Depreciation Fund is that every business principle demands that once an undertaking is started, wherever the initial capital comes from or on whatever terms it may be borrowed, the plant should be maintained at its full value out of revenue; and where this is impossible by mere repairs year after year it must be done by means of a Depreciation Fund, as a private company would do. True, the company would not in addition require a Sinking Fund, but then it is a recognised principle that no permanent local debt should exist even for trading purposes, and this Sinking Fund should be the only difference between the practice of a municipality and that of a private company in a similar undertaking, so far as the keeping of accounts is concerned.

Which of these views are we to accept as the soundest finance? Parliament and the Departments have at no time given a decisive answer to the question, but I think the latter is the true view in the cases of reproductive undertakings which I am considering. It is very undesirable that the system of borrowing and re-borrowing every thirty years or so should become a fixed principle, as it certainly will unless the general present practice is changed; and while it is a first principle that there should be no permanent local debt it is curious that something very like a permanent debt for reproductive undertakings can be the only outcome of present methods. But are we then to advocate that every municipality should be obliged to institute an adequate Depreciation Fund while other matters remain as they are at present? We must admit that to do so would be to take the life of the subject into account twice over, with the result that the first generation would be burdened twice as much as the second and succeeding generations. We are, then, landed into something like a dilemma. Every municipal reproductive undertaking subject to depreciation which ordinary annual expenditure on repairs cannot obviate, ought on business principles 
to set aside an adequate Depreciation Fund. But this would be inequitable to the first generation if it has also to pay a Sinking Fund based on the life of the subject. From this dilemma arises the existing confusion of practice.

One of the recommendations of the Committee on Repayment of Loans is "that power should be given to the sanctioning authority to make it a condition of their sanction that provision should be made for the probable annual average cost of repairs during the currency of the loan," and such a Repairs Fund seems to be confused with a Depreciation Fund. But even if you equalised the annual amount to be set aside for mere repairs over a period of years you have not provided against depreciation. The repairs, of course, must be done out of revenue, but they cannot prevent depreciation in these undertakings, for the time comes when complete renewal of some part-say, tramlines-is necessary. This distinction between repairs and renewals is vital, and if, as it seems probable, the Committee intended merely that the sum required for repairs over a period of say, thirty years, should be estimated in such a way as to make the first year bear as much of the cost as the last, the point I am urging is quite unaffected by it. The repairs are done now in some way or other out of revenue, and the method of meeting repairs is an entirely different question from the complete renewal of plant. That the plant shall be kept in fair working order during its life by necessary repairs has been assumed throughout this paper, and in practice the suggestion of a Repairs Fund may be found valuable; but a corporation which has a sinking Fund and a Repairs Fund will have to borrow afresh whenever it wants to renew, just as it would have to do if it merely met the necessary repairs each year from that year's revenue. So far as the Report of the Select Committee is concerned there is no way out of the dilemma.

The only way out of the muddle is to recognise that there are classes of reproductive undertakings which are now being forced into a bed of Procrustes which they can only fit by violence, and it is possible to give very strong theoretical as well as practical reasons in favour of a change of system. The function of a Depreciation Fund is clear; it is required in certain undertakings where the annual expenditure on repairs does not balance the loss of value due to wear and tear, and such factors as obsolescence. Its function is maintenance of value where the disbursements for repairs cannot by the nature of the plant obviate shrinkage of value, and it should therefore be of such a 
character that the value of the plant, plus the Depreciation Fund, is always equal to the original capital expended. No sound trading company would declare its profits in any year until this charge had been made upon the receipts of the undertaking, otherwise the capital would not be kept intact. Obviously, then, the Depreciation Fund is determined by the life of the subject, for if a tram car lasts five years, one-fifth of its value should be written off capital account each year, and that sum set aside for depreciation. The function of a Sinking Fund is to repay debt; but the length of the period may be fixed in each case by a variety of considerations. In the case of some municipal debts, the period, as I showed, has no reference to the life of the subject. A debt for a permanent subject is usually paid off in two generations. But in many of the early cases of loans for sanitary and public health purposes it was found to be very convenient to take the probable useful life as the maximum period allowable, and usually the period granted was much shorter. Depreciation, therefore, was met by the Sinking Fund just as it sometimes is in the case of a mine or other subject which will be worked out in a measurable period, and in most cases this was not only justifiable on the ground of convenience, but also on the ground that it was the only possible way of distributing the burden in an equitable manner for unproductive works. When the large borrowings for reproductive works began this same system was followed, and is followed to-day, and if we are prepared to say that re-borrowing at the end of the Sinking Fund period to reinstate the works is the proper principle for municipal reproductive undertakings we shall acquiesce in this application of the system. The Sinking Fund in that case is the Depreciation Fund. But most students of municipal finance, whatever their views on the sphere of municipal trading may be, will not hesitate to condemn a system which means practically a permanent debt for the capital of these undertakings. The only alternative as the law now stands is for municipalities to institute a Depreciation Fund in addition, and that, as I said, may be reasonably opposed as too great a burden upon the first generation, though a few municipalities have accepted the burden and taken the life of the subject into account twice over.

A better way than either of these, which at the same time avoids the Scylla of a permanent debt and the Charybdis'of overburdening the first generation, would be to insist upon a Depreciation Fund in every reproductive undertaking in which maintenance of value is impossible without it, and at the 
same time to have a Sinking Fund which is not limited to the life of the subject. In the nature of a Sinking Fund there is nothing which requires that the life of the subject should be the determinant of the period. In certain cases it may be convenient; in those with which I am specially concerned it is neither convenient nor reasonable if a Depreciation Fund is kept. In this way we obtain a scheme by which a municipality may spread the repayment of its debt for a particular undertaking over a convenient period of years and not require again to borrow capital for it, except, of course, where a large extension is to be made. If the equated life of a tramway undertaking is thirty years and the Depreciation Fund is fixed upon that basis, there is no reason whatever why the life of the subject should also fix the Sinking Fund period, but every reason against it. The repayment of the debt is a matter to be decided by quite other principles, and I see no reason why the Sinking Fund period should not be two generations or so.

It would be possible to show that such a scheme would give a satisfactory solution to many of the minor difficulties such as the postponement of the Sinking Fund during the period of construction; but I must close by saying that while such a scheme would lessen the burden of the present in a very few towns it would increase it in most places and would increase it over the whole. That this is not an undesirable result when we consider the magnitude of the issues, and the necessity of safeguarding the future will, I think, be generally admitted; and any slight difficulties of administration which it might involve would be more than counterbalanced by the gain, since our only alternative seems to be the present chaos with its attendant risks to posterity, resulting from statutory conditions which have no strong support from theory or from business experience.

S. H. TURNER 